This is a self-archived final draft version of the original article. It differs from the original in pagination and typographic detail.

To cite the article:

Viljamaa, A., Varamäki, E. \& Joensuu-Salo, S. 2017. Best of both worlds? Persistent hybrid entrepreneurship. Journal of Enterprising Culture 25 (4), 339-359.

https://doi.org/10.1142/S0218495817500133

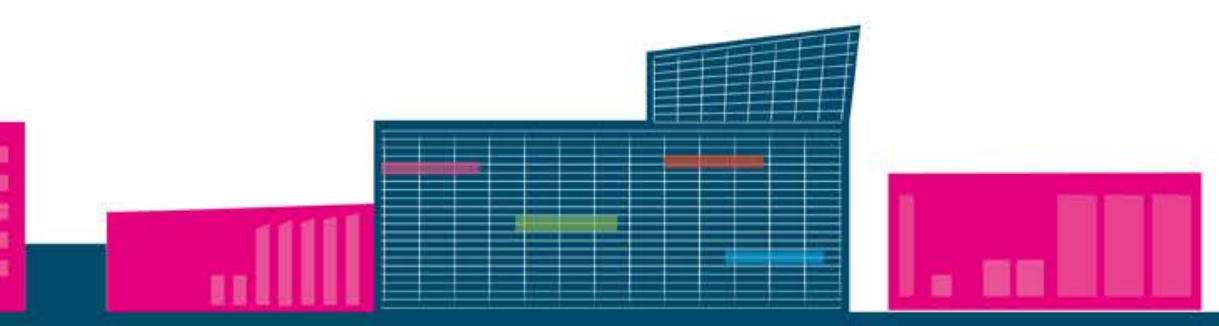




\title{
Best of both worlds? Persistent hybrid entrepreneurship
}

\author{
Anmari Viljamaa*, Elina Varamäki \& Sanna Joensuu-Salo
}

Seinäjoki University of Applied Sciences

*corresponding author

\begin{abstract}
Hybrid entrepreneurs (HEs) represent a considerable share of all entrepreneurial activity. Yet little is known about the phenomenon. In this study we examine the differences between transitory HEs, who expect to make the transition to full-time entrepreneurship, and persistent HEs, who view their part-time status as permanent. With data collected from 848 academic HEs we find that only a small minority considers full self-employment likely in the near future and that self-fulfillment is the most significant motive for entrepreneurial activities. The results suggest that persistent hybrid entrepreneurship should be viewed as a form of entrepreneurship in its own right, and that even partial entrepreneurship has the potential to lengthen careers and improve wellbeing at work. Hybrid entrepreneurship offers the entrepreneurially inclined employees the best of both worlds.
\end{abstract}




\title{
Best of both worlds? Persistent hybrid entrepreneurship
}

\begin{abstract}
Hybrid entrepreneurs (HEs) represent a considerable share of all entrepreneurial activity. Yet little is known about the phenomenon. In this study we examine the differences between transitory HEs, who expect to make the transition to full-time entrepreneurship, and persistent HEs, who view their part-time status as permanent. With data collected from 848 academic HEs we find that only a small minority considers full self-employment likely in the near future and that self-fulfillment is the most significant motive for entrepreneurial activities. The results suggest that persistent hybrid entrepreneurship should be viewed as a form of entrepreneurship in its own right, and that even partial entrepreneurship has the potential to lengthen careers and improve wellbeing at work. Hybrid entrepreneurship offers the entrepreneurially inclined employees the best of both worlds.
\end{abstract}

KEYWORDS: hybrid entrepreneurship, part-time entrepreneurship, survey

\section{Introduction}

Entrepreneurship research typically views entrepreneurship as a dichotomous phenomenon; an individual either is an entrepreneur or not. Yet many nascent entrepreneurs, i.e. individuals in the process of starting a new venture, are simultaneously also in full-time employment (Reynolds et al. 2004, Gelderen et al. 2005, Bosma et al. 2008). Also studies focusing on the occupational choice between employed work and self-employment have a tendency to view the choice as an either-ordecision (e.g. Singer et al. 2011). In practice hybrid entrepreneurs (HEs), i.e. entrepreneurs with a primary wage job (Folta et al. 2010, 253), represent a significant share of entrepreneurial activity. The phenomenon is, however, among the least understood aspects of nascent entrepreneurship (e.g. Folta et al. 2010, Reynolds et al. 2004).

When entrepreneurship research has examined hybrid entrepreneurship, focus has largely been on part-time entrepreneurship as an entry strategy, i.e. as a route to full-time entrepreneurship (e.g. Petrova 2012), and on the impact of part-time vs. full-time entry on venture success (e.g. Gelderen et al. 2005). There is, however, evidence to suggest that HEs are systematically different from entrepreneurs opting for full-time self-employment immediately (Folta et al. 2010). Further, there is also evidence to suggest that combining entrepreneurial activities with salaried employment may be a permanent condition for many (e.g. Varamäki et al. 2012, Viljamaa et al. 2014). This suggests that hybrid entrepreneurship may be a distinct category of entrepreneurial activity and should be treated as such.

The aim to the paper is gain a better understanding of whether hybrid entrepreneurship can be considered an entry strategy into full-time entrepreneurship rather than a form of entrepreneurship in itself. To that end we examine the profiles of transitory hybrid entrepreneurs (THEs), i.e. HEs who consider full-time entrepreneurship probable, and persistent hybrid entrepreneurs (PHEs), i.e. 
HEs who view their hybrid condition as permanent, and explore their motivations. In specific, our objective is to compare the two groups and to determine how they differ in background, motives, job satisfaction and entrepreneurial inputs. Moreover, we examine the effect of background, motives, job satisfaction and entrepreneurial inputs on intention to transition to full-time entrepreneurship. We test a linear regression model to explain the effect of different factors.

\section{Literature}

Folta et al. (2010) use the label hybrid entrepreneurship for individuals who mix entrepreneurship and wage employment. Lith (2010) defines part-time entrepreneurship as entrepreneurship by individuals who support themselves primarily by other means. Petrova's (2011) study on part-time entrepreneurs focuses on nascent entrepreneurship and defines part-time status through hours worked on business activities. Hybrid entrepreneurs (HEs) represent a significant share of all entrepreneurial activity (Folta et al. 2010), and as such, hybrid entrepreneurship is an important societal phenomenon. At the same time it is perhaps one of the least understood aspects of entrepreneurship (Reynolds et al. 2004), and further research is needed (Burke et al., 2008; Folta et al., 2010).

No commonly agreed upon definition exists for hybrid or part-time entrepreneurs, but examples provided by e.g. Eurofound (2011) range from farming side-activities to IT consulting, suggesting that the phenomenon can be approached from various perspectives. Even practical definitions of hybrid entrepreneurship vary. Eurofound (2011) notes that in some countries part-time entrepreneurship is defined as working fewer than 35 hours per week. This approach is followed by Petrova (2011), who views entrepreneur's time as an investment determined partly by the level of knowledge the entrepreneur has on his or her probability of success. In some contexts the share of income derived from entrepreneurship is used to define part-time status (Eurofound 2011). Mungaray and Ramirez-Urquidy (2011) define those whose entrepreneurial income is a maximum of 75 per cent of total income as part-timers. Gruenert (1999) uses the term 'second job entrepreneur', and the definition includes individuals with primary paid jobs and secondary employment as self-employed in unincorporated businesses. Markantoni et al. (2012), who study side-activity entrepreneurs, refer in their definition to side income and a rural setting.

In our study, following Lith (2010) and Folta et al. 2010) we define hybrid entrepreneurs (HEs) as individuals who are active as entrepreneurs but do no support themselves primarily by their enterprise. Thus we do not focus solely on hours spent on running the business but nor do we assume that hybrid entrepreneurship is necessarily an entry strategy (cf. Folta et al. 2010).

Although taking the hybrid path to entrepreneurships seems to lead to better survival rates (Raffiee \& Feng 2014), starting a part-time business is not necessarily indicative of a desire to become a fulltime entrepreneur. For example retiree-HEs are unlikely to plan transition to full-time entrepreneurship (Tornikoski et al. 2015). Also, Akola et al. (2007) find in their sample of journalists and interpreters that about $40 \%$ plan to continue on part-time basis. If the HE is not in fact a nascent entrepreneur, i.e. has no plans for full-time entrepreneurship, part-time activities may be continued indefinitely. National studies (Akola et al. 2007, Entrepreneurship Review 2010) also show that as much as $4 \%$ of the employed workforce and $4 \%$ of the non-employed population (e.g. students, pensioners) are involved in entrepreneurial activities on part-time bases. Part-time entrepreneurship is particularly likely for employees whose jobs allow some flexibility in working hours (Entrepreneurship Review 2010). Hybrid entrepreneurs often also have relatively high wage 
income (Lith 2010, Gruenert 1999). This could be explained by the fact that high wage income makes it possible to invest in part-time entrepreneurship. On the other hand, it could be that individuals with high wage income are prevented from becoming full-time employees by the high opportunity costs.

Hence, there is a need to better understand the distinction between HEs as nascent entrepreneurs, i.e. HEs who consider the transition to full-time entrepreneurship probable, and HEs as part-time entrepreneurs with no full-time entrepreneurial intentions. We label the former transitory hybrid entrepreneurs (THEs) and the latter persistent hybrid entrepreneurs (PHEs). In the following we explore the factors related to HEs motives, their job satisfaction and the role of entrepreneurship in their income and time expenditure.

Kirkwood (2009) suggests that there are four key drivers for entrepreneurial motivation: desire for independence, monetary motivations, work-related motivation and family-related motivation. However, as her study focused at business founders who employ at least one other person, and are in fact fully employed in their own firms, other motivations should be considered for HEs. Petrova (2011) argues that part-time entrepreneurship may be explained by uncertainty about entrepreneurial ability: simultaneous entrepreneurship and employment give the aspiring entrepreneur an opportunity to test his or her abilities as an entrepreneur. According to Petrova's (2011) model, an individual increases time spent on entrepreneurial activities if evidence from the testing is favorable and thus moves to full-time entrepreneurship. Likewise, if evidence is inconclusive, testing is continued, and if adverse, time spent is reduced and individual returns to full-time wage employment. The underlying assumption is that a person starting a business is naturally aiming at full-time entrepreneurship, but this may not be the case; hybrid entrepreneurship can be of long duration and the hybrid entrepreneurs do not necessarily seek growth that would enable them to become full-time entrepreneurs (Varamäki et al. 2012, Viljamaa et al. 2014). Recent GEM studies have consistently shown that Finland has a high level of entrepreneurial potential but despite this, entrepreneurial intentions remain low (Stenholm et al. 2012, Stenholm et al. 2015). About every third Finnish adult has a fear of failure that seemingly prevents entrepreneurship (Stenholm et al. 2015) and, while the prevalence of fear is not particularly high in comparison to e.g. other Nordic countries, it is suggestive of a risk-averse atmosphere.

Folta et al. (2010) found in their study some support for the idea that hybrid entrepreneurship is a path to transition into self-employment. Only the HEs with the highest income from entrepreneurial activities made the transition, which may be viewed as support for the idea that HEs test their business idea or their own abilities, and those who get the most favorable feedback make the transition. However, as Folta et al. (2012) base their analysis on income data, the result does not provide us with information of the HEs intentions or motivations as they start their part-time business or during their hybrid entrepreneurship.

In addition to financial factors, nonmonetary benefits of hybrid entrepreneurship should also be considered. Folta et al. (2010) propose that second jobs as entrepreneurs may be preferable to second wage jobs because of psychological benefits. Mungaray and Ramirez-Urquidy’s (2011) results suggest that part-time efforts may relate to a focus on non-pecuniary aspects rather than profit maximization. According to Douglas and Shepherd (2002), attitudes to risk and independence are important determinants of self-employment intentions but neither expectations of higher income nor lower work effort are significant determinants. Need for independence and self-fulfillment are frequently mentioned in studies on (full-time) entrepreneurial motivations (e.g. Burke et al., 2008; 
Segal et al., 2005; Lange, 2012). Thorgren et al. (2014) focus on passion as a main motive for HEs and find it is associated with spending more time on the business. Varamäki et al. (2012), Viljamaa and Varamäki (2014) and Viljamaa et al. (2015) find self-fulfillment also a key motive for HEs, although supplementary income is also important. All in all, it appears that hybrid entrepreneurship offers to the risk-averse an opportunity to enjoy at least some of the benefits of self-employment without facing the switching costs of direct self-employment. Also, it should be recognized that a part-time business may begin as a tool for better organizing freelance activities (see e.g. Akola et al. 2007; Kitching \& Smallbone 2012); in such cases the HE may not view his hybrid activities as entrepreneurship in the traditional sense of the word.

Entrepreneurship may also be motivated by push rather than pull factors (e.g. Moore and Mueller 2002; Kirkwood, 2009; cf. Dawson and Henley, 2012), i.e. an individual may find that selfemployment is the only viable option, or may be driven towards self-employment by dissatisfaction with salaried employment. For salaried HEs part-time entrepreneurship may play a similar role; an employed individual may feel insecure about the continuity of the job and start a part-time business as career insurance. Hence, hybrid entrepreneurship may be viewed as a risk-reducing career strategy. At the same time, as entrepreneurs have higher satisfaction levels than employees (e.g. van Praag and Versloot, 2007), hybrid entrepreneurship may serve as a counterpoint to dissatisfactory work and provide an outlet for entrepreneurial energies and may hence increase HEs' overall satisfaction and thus lead to increased job satisfaction. This argument is supported by Varamäki et al.'s (2012) study in which almost a third of the HE respondents were in business in a field they had neither formal training nor work experience in, and over a half claimed that their business originated from a hobby or other object of personal interest.

In sum, HEs may be motivated by the intention to become full-time entrepreneurs (i.e. testing), by psychological rewards such as self-fulfillment, by additional income, or by push-factors relating to salaried employment. Based on the earlier studies we expect that THEs have a higher share of income from their entrepreneurial activities, are more interested in firm growth and spend more time on their business than PHEs do. Satisfaction with salaried employment we expect to be greater with PHEs. Both THEs and PHEs should be motivated at least partly by psychological rewards and by additional income. Assuming need for independence as a motivating factor for THEs, we expect PHEs to be relatively more often than THEs employed in executive or supervisory tasks.

The maturity of the hybrid enterprise should, on average, be greater for PHEs than for THEs. We argue in line with Petrova (2011) that an HE who is planning fulltime entrepreneurship is likely to exit hybrid status by becoming a fulltime entrepreneur or by closing down the business activities if feedback is averse. A third possibility is a change in the entrepreneur's expectations; a THE becomes a PHE as his or her faith in the probability of realizing a full-time business is lost.

GEM data (Stenholm et al. 2015) shows that in Finland the share of men (6.6\%) involved in early stage entrepreneurial activity is larger than that of women (4.6\%) and the gender imbalance is even greater when it comes to enduring business activities: $9.1 \%$ of men and $4.0 \%$ of women are established business owners. Also, men are more likely to have high growth aspirations (ibid.) Since men are more likely to be entrepreneurially involved altogether, and are more like to have an interested in growing their business, we expect men to be more likely THEs than women.

Age may also be a factor. Previous studies have shown that in general older people are less likely to engage in entrepreneurial activity (Curran \& Blackburn 2001, Hart et al. 2004). Elderly entrepreneurs are likely to have lower objective need for increase in income. Age seems to decrease 
growth motivation (Foley 1984; Davidsson 1989; cf. Alsos \& Kolvereid 1999, Westhead \& Wright 1998). According to Gray (2004) growth orientation is at its highest for those under 40 and decreases clearly as age increases. We expect that interest in business growth is higher for THEs than for PHEs and that the THEs are on average younger than PHEs.

\section{Data gathering and the respondents}

No ready databases on HEs are available. Previous studies (Varamäki et al. 2012, Akola et al. 2007, Gruenert 1999) have shown that HEs tend to be more highly educated than micro-entrepreneurs on average, and GEM studies in Finland show that highly educated individuals are more prone to early-stage entrepreneurial activity than others (Stenholm et al. 2013, Stenholm et al. 2015). Hence, individuals with higher education were deemed of particular interest for the study. The members of two labour market organisations of academically trained employees were targeted: The Finnish Association of Business School Graduates and Academic Engineers and Architects. The total number of members in these two associations is 120000 while the total population of employees in Finland is 2.4 million. The data was collected through an internet survey in March 2014. A link to the survey was sent to all members of the Association with a covering message explaining that the survey is aimed at members with part-time entrepreneurial acitivities. A further identifying question asked respondents to indicate the nature of their entrepreneurial activity (primary full-time or secondary part-time, and if secondary part-time, concurrent with what). All in all 848 responses were received. $79 \%$ of the respondents were HEs beside salaried employment. $15 \%$ of the HEs were retired, $5 \%$ were students and $5 \%$ were unemployed.

$68 \%$ of the respondents were men. The mean age of the respondents was 47.6 years. The respondents' experience of hybrid entrepreneurship was about nine years on average. $15 \%$ of the respondents had been engaged in part-time entrepreneurship less than two years, but more than half (53.5 \%) had already more than five years of part-time entrepreneurship experience. Most respondents' field of business is expert services (64\%). 13\% are involved in other services, $9 \%$ each in primary production and trade, and finally, $4 \%$ in manufacture and construction. The number of expert service providers is somewhat higher than in for example Varamäki et al.'s (2012) data, but this is understandable in a target group whose skillset naturally lends itself to expert service provision. The gender ratio, on the other hand, is very similar to that what could be expected based on GEM studies or previous studies by Gruenert (1999) and Varamäki et al. (2012), although in contrast to Lith’s (2010) analysis. Folta et al. (2010) examine only male HEs.

In addition to descriptive statistics, cross-tabulation, chi-square test, t-test and factor analysis are used in data analysis.

\section{Measures}

Transition intentions. The intention to transition to full-time entrepreneurship was examined by asking the respondents to indicate the probability of becoming a full-time entrepreneur within the next three years on a scale of 1 (=very unlikely) to 5 (=very likely). For the purposes of further analysis and comparison of transitory and persistent hybrid entrepreneurs, the respondents rating the likelihood of full-time entrepreneurship as 1 or 2 were classified as persistent hybrid entrepreneurs (PHEs, $\mathrm{n}=568$ ) and those rating the likelihood of full-time entrepreneurship 4 or 5 as transitory 
hybrid entrepreneurs (THEs, $n=124$ ). Respondents giving the value 3 were excluded from later analysis.

For regression analysis, a scale of transition intentions was created. The scale had two items (the probability of full-time entrepreneurship within the next three years, scale 1 to 5 , and the probability of full-time entrepreneurship at some point in the work career, scale 1 to 5). Cronbach's alpha for the scale was 0.82 , thus the scale had high reliability ratio.

Duration of hybrid entrepreneurship. The respondents were asked to indicate in which year the they had begun their current part-time business. Respondents involved in running several part-time businesses were asked to reply with reference to the eldest still functioning part-time business. The duration of hybrid entrepreneurship was then obtained by deducting the year of foundation from year of the study.

Growth orientation. The respondents were asked to indicate to what degree they consider increasing the turnover of their business an objective. The four alternatives offered range from 'I aim for strong growth' to 'I plan to wind the business down' (see also Table 4). This measure has been tested several times in Finnish context (Pk-yritysbarometri 2/2014).

Entrepreneurial income. The respondents were asked to indicate the share of total income that came from entrepreneurship in the last 12 months as a percentage (1\%-100\%).

Time spent on hybrid entrepreneurship. The respondents were asked how many hours per week they spend on their enterprise (annually time spent divided by 52).

Position in wage employment. The respondents were asked to choose the alternative that best describes their position in wage employment, the alternatives given being Top management, Middle Management / supervisory position, Expert position, Employee position and Other. The replies given to the alternative 'Other, what?' were analysed and recategorized if possible. The responses that could not be categorized were eliminated from the analysis of this item. This variable was not used in regression analysis.

Job satisfaction. The respondents were asked how satisfied they are with wage employment as a whole (content, challenges, compensation, etc.) on a scale of 1 (=very dissatisfied) to 5 (=very satisfied).

Motives. The motives of HEs were explored with an instrument consisting of 15 statements relating to their HE activities. The respondents were asked to indicate their agreement or disagreement with the statements on 5-point Likert scale from 1 (=totally disagree) to 5 (=totally agree). The statements were developed in the course of a multiphase study project focused on part-time entrepreneurs and were tested on other datasets before use here (Viljamaa \& Varamäki 2014; Viljamaa et al. 2014). Factor analysis showed three main motivational categories for HEs (see Table 1) Testing $(\alpha=.808)$ fits the view of part-time entrepreneurship as a temporary phase prior to fulltime entrepreneurship. Fulfillment $(\alpha=805)$ views entrepreneurship as an opportunity for doing interesting things and finding self-fulfillment. Security $(\alpha=.650)$ focuses on entrepreneurship as a back-up plan in case of unemployment or threat of unemployment. In addition to these three, Income as a motive was included as a single item in the instrument. 


\section{TABLE 1. TESTING, FULFILLMENT, SECURITY AND ADDED INCOME MOTIVATIONS.}

\begin{tabular}{|l|l|}
\hline Sum variable & items \\
\hline $\begin{array}{l}\text { Testing } \\
(\alpha=0.808)\end{array}$ & $\begin{array}{l}\text { I would rather be a full-time entrepreneur than in full-time salaried } \\
\text { employment }\end{array}$ \\
& $\begin{array}{l}\text { As a part-time entrepreneur, I am testing a business idea with a view to full- } \\
\text { time entrepreneurship }\end{array}$ \\
& $\begin{array}{l}\text { Part-time entrepreneurship is an intermediate phase before full-time } \\
\text { entrepreneurship }\end{array}$ \\
\hline $\begin{array}{l}\text { Fulfillment } \\
(\alpha=0.805)\end{array}$ & $\begin{array}{l}\text { I am sure I will never be a full-time entrepreneur (reversed) } \\
-\end{array}$ \\
\hline $\begin{array}{l}\text { Security } \\
(\alpha=0.650)\end{array}$ & $\begin{array}{l}\text { The most important thing about entrepreneurship is the opportunity for self- } \\
\text { fulfillment }\end{array}$ \\
\hline Added income & $\begin{array}{l}\text { The business is for me partly a back-up plan in case of unemployment } \\
\text { to start a part-time business. }\end{array}$ \\
\hline
\end{tabular}

\section{Results}

Only $16 \%$ of the HEs can be classified as THEs whereas a clear majority (70 \%) are PHEs and consider full-time entrepreneurship within the next three years unlikely at best (Table 2). This strongly supports the suggestion that there is a category of persistent hybrid entrepreneurship distinct from hybrid entrepreneurship as an entry strategy.

In the following, PHEs ( $n=568)$ and THEs $(n=124)$ are compared. HEs who chose ' 3 ' in reply to this question have been excluded from the analyses. Table 2. Intention to transition.

TABLE 2. INTENTION TO TRANSITION.

\begin{tabular}{|l|c|c|}
\hline $\begin{array}{l}\text { Probability of full-time entrepreneurship within the next } \\
\text { three years }\end{array}$ & $\mathbf{n}$ & $\%$ \\
\hline 1= very unlikely & 389 & 48 \\
2 & 179 & 22 \\
3 & 124 & 15 \\
4 & 79 & 10 \\
5=very likely & 45 & 6 \\
\hline Total & 816 & 100 \\
\hline
\end{tabular}

Gender. Based on previous studies, we expected that men are more likely to be THEs than women. The gender distribution (Table 3) shows that while men are indeed more likely to be THEs, the share of women in that category is greater than the share of women among PHEs. The difference is suggestive but not statistically significant $(\mathrm{p}=0,068)$.

\section{TABLE 3. GENDER OF PHES AND THES.}




\begin{tabular}{|l|c|c|}
\hline \multirow{2}{*}{ Gender } & $\begin{array}{c}\text { PHEs } \\
(\mathrm{n}=564)\end{array}$ & $\begin{array}{c}\text { THEs } \\
(\mathrm{n}=123)\end{array}$ \\
\cline { 2 - 3 } & $\%$ & $\%$ \\
\hline female & 30 & 38 \\
male & 70 & 62 \\
\hline $\mathrm{p}=0,068$ & \multicolumn{2}{|c|}{} \\
\hline
\end{tabular}

Age. Based on previous studies, we expected THEs are likely to be younger than PHEs. This was confirmed in by the data: the average age for PHEs was 48.5 years and for the THEs 44.8 $(p=0.002)$. However, as early-stage entrepreneurship is highest in the age group 35-44 (Stenholm et al. 2015), one might have expected an even greater difference.

Growth orientation. Altogether slightly over half of the respondents seek growth, but only $6 \%$ aim for strong growth. PHEs and THEs differ clearly in growth orientation $(\mathrm{p}=0.000)$. Very few PHEs aim for strong growth, whereas over a fifth of the HEs planning a transition to full-time entrepreneurship consider strong growth as their objective (Table 4).

TABLE 4. GROWTH ORIENTATION OF PHES AND THES.

\begin{tabular}{|c|c|c|}
\hline \multirow[t]{2}{*}{$\begin{array}{l}\text { Is increasing the turnover of your business an } \\
\text { objective for you? }\end{array}$} & $\begin{array}{l}\text { PHEs } \\
(\mathrm{n}=567)\end{array}$ & $\begin{array}{l}\text { THEs } \\
(\mathrm{n}=124)\end{array}$ \\
\hline & $\%$ & $\%$ \\
\hline I aim for strong growth & 2 & 21 \\
\hline I aim for growth according to opportunities & 38 & 60 \\
\hline I aim to maintain current level & 53 & 17 \\
\hline I plan to wind the business down & 7 & 2 \\
\hline$p=0,000$ & & \\
\hline
\end{tabular}

Duration of hybrid entrepreneurship. In our analysis PHEs have a clearly longer history of hybrid entrepreneurship than THEs. Whereas PHEs have on average 10.2 years of hybrid entrepreneurship behind them, THEs have only 6.2 years. The difference is statistically very significant $(\mathrm{p}=0.000)$ and in line with our expectations.

Entrepreneurial income and time expenditure. THEs receive on average $14.3 \%$ of their total income from their business, a somewhat greater share than the PHEs with $11.4 \%$. The difference is not a great as one might expect, however, considering that THEs expect to become full-time entrepreneurs within the next three years. Also, the result is indicative rather than statistically significant $(p=0.067)$. There is, however, a clear and statistically significant difference in time expenditure: THEs spend on average 9.5 hours/week on their business whereas PHEs spend only 5.5 hours/week $(\mathrm{p}=0.000)$. 
Position and job satisfaction. Although HEs are, compared to the workforce on average, more often in management positions, no significant difference in position was found between PHEs and THEs. However, there was a statistically significant difference in job satisfaction: PHEs' average was 3.7 and THEs' 3.2 ( $\mathrm{p}=0.000$ ). This demonstrates clearly that intention to transition - or lack of it - is related to satisfaction with current employment (Table 5). We also find that the HEs for whom added income is an important motive, are slightly less often satisfied with their wage employment $(p=0.048)$. This may indicate a tendency to emphasize monetary benefits.

TABLE 5. SATISFACTION WITH WAGE EMPLOYMENT OF PHES AND THES.

\begin{tabular}{|l|c|c|c|}
\hline & $\begin{array}{c}\text { PHEs } \\
(\mathrm{n}=457)\end{array}$ & $\begin{array}{c}\text { THEs } \\
(\mathrm{n}=92)\end{array}$ & \multirow{2}{*}{ p-value } \\
\cline { 2 - 3 } & average & average & \\
\hline $\begin{array}{l}\text { How satisfied are you with your wage } \\
\text { employment as a whole (content, } \\
\text { challenges, compensation, etc.)? }\end{array}$ & 3,7 & 3,2 & \multirow{2}{*}{0,000} \\
\hline
\end{tabular}

Motives. PHEs score considerably lower than THEs on the variable Testing, which is natural since the testing measurement items relate to plans for transition. More interestingly, there is also a clear distinction between PHEs and THEs in Self-fulfillment and Security motives. THEs rate Selffulfillment at average of 4.3 and PHEs at average of $3.8(\mathrm{p}=0.000)$. Self-fulfillment is thus a very important motivating factor for both groups but clearly more important for those who expect to transition to full-time entrepreneurship. Somewhat surprisingly, a very similar difference is found between PHEs and THEs in Security as a motivating factor: THEs rate Security at an average of 3.2 and PHEs at an average of $2.7(\mathrm{p}=0.000)$. Added Income as motivating factor is apparently unrelated to the HEs transition intentions ( $\mathrm{p}=0.909)$ (Table 6).

TABLE 6. MOTIVES OF PHES AND THES.

\begin{tabular}{|l|c|c|c|}
\hline \multirow{2}{*}{ Motives for hybrid entrepreneurship } & $\begin{array}{c}\text { PHEs } \\
(\mathrm{n}=564)\end{array}$ & $\begin{array}{c}\text { THEs } \\
(\mathrm{n}=124)\end{array}$ & \multirow{2}{*}{$\mathrm{p}$-value } \\
\cline { 2 - 4 } & average & average \\
\hline Testing & 2,5 & 4,0 & 0,000 \\
Self-fulfillment & 3,8 & 4,3 & 0,000 \\
Security & 2,7 & 3,2 & 0,000 \\
Income & 3,1 & 3,1 & 0,909 \\
\hline
\end{tabular}

A model for transition intention was tested using linear regression analysis. First, the normality of scales was tested using Kolmogorov-Smirnov and Shapiro-Wilk -tests, which showed that all the variables in our model were normally distributed. The VIF-values were checked to see that there was no problem with multicollinearity. Table 7 shows the result of the linear regression analysis. In the model 1 all the tested variables are presented. In the model 2, all the non-significant variables are excluded from the analysis. Results show, that the most important variable in the model 2 is the 
motive "testing" ( $\beta=0.61^{* * *}$ ). That explains the majority of the variance in the model. Other statistically significant variables are age $(\beta=-0.13 * * *)$, growth orientation $(\beta=0.13 * * *)$ and the amount of income gained from hybrid entrepreneurship $\left(\beta=0.06^{*}\right)$. The model explains 53 percent of the variance in the transition intention.

TABLE 7. LINEAR REGRESSION ANALYSIS ON TRANSITION INTENTIONS

\begin{tabular}{|c|c|c|}
\hline & Model 1: $\beta$, significance & Model 2: $\beta$, significance \\
\hline \multicolumn{3}{|l|}{ Independent variables } \\
\hline Gender & -0.01 & \\
\hline Age & $-0.10^{* *}$ & $-0.13^{* * *}$ \\
\hline Duration of hybrid entrepreneurship & -0.01 & \\
\hline Growth orientation & $0.16^{* * *}$ & $0.13^{* * *}$ \\
\hline Entrepreneurial income & $0.09 * *$ & $0.06^{*}$ \\
\hline Time spent on hybrid entrepreneurship & -0.02 & \\
\hline Job satisfaction & -0.05 & \\
\hline Motive: Testing & $0.57 * * *$ & $0.61 * * *$ \\
\hline Motive: Fulfilment & 0.01 & \\
\hline Motive: Security & 0.03 & \\
\hline Motive: Added income & -0.01 & \\
\hline \multicolumn{3}{|l|}{ Model fit statistics } \\
\hline Adjusted R² & 0.52 & 0.53 \\
\hline F-statistics & $60.080^{* * *}$ & $217.722 * * *$ \\
\hline
\end{tabular}

\section{Discussion}

In this paper we have explored the motives and profiles of academic hybrid entrepreneurs in order to better understand whether and to what extent is hybrid entrepreneurship in fact an entry strategy into full-time entrepreneurship. To that end we compared the profiles of transitory hybrid entrepreneurs (THEs), i.e. HEs who consider full-time entrepreneurship probable, and persistent hybrid entrepreneurs (PHEs), i.e. HEs who view their hybrid condition as permanent, and explore their motivations.

On a general level, the personal profiles of academic HEs largely fit the expectations formed on basis of earlier research. Services and specifically expert services are the most common field of business in our dataset. This is in line with other studies both in the field of hybrid entrepreneurs (e.g. Lith, 2010, Gruenert, 1999) and academic entrepreneurs (e.g. Heinonen et al. 2006, Akola, 2007). Men are more likely to have part-time entrepreneurial activities (Grunert, 1999, Varamäki et al., 2012, cf. Lith, 2010), and in our study also, the majority of HEs are male.

A clear majority of the HEs in our study have a lengthy history of hybrid entrepreneurship. On average, the HEs have been engaged in entrepreneurial activities for nine years. Similar results were found by Varamäki et al. (2012); in their data the average length of hybrid activities was slightly over ten years. There is some difference between PHEs and THEs in the duration of hybrid entrepreneurship, with THEs having the lower average duration (six years vs. ten years), but the difference is not as great as one might expect. In other words, it if the THEs are testing their 
business idea or their own capabilities as entrepreneurs (see e.g. Petrova 2011, Folta et al. 2010), they are taking rather long to do so.

Our study thus affirms that hybrid entrepreneurship is often a persistent mode of entrepreneurship. Most HEs do not view themselves as nascent entrepreneurs, i.e. future full-time entrepreneurs, and even fewer plan for growth entrepreneurship. Only six percent of the HEs consider it very likely that they will become self-employed within the next three years and only a fifth of the THEs aim for strong growth.

We also examined the motivations of HEs. Testing a business idea prior to becoming a full-time entrepreneur, i.e. the classic motivation assigned to nascent entrepreneurs who remain in salaried employment as they start their business, is indeed present as a motive but it is not by any means universal. We also find that self-fulfillment motives are emphasized with THEs. This may be related to the fact that THEs also score somewhat lower on job satisfaction. The less attractive one's work situation, the more attractive entrepreneurship appears and the more probable the transition to full-time also appears. Interestingly, security motives were also highlighted by THEs. This may be due to economic conditions: if the hybrid enterprise is established partly to provide 'career insurance' in a turbulent economic situation, continuing economic problems may be interpreted as increasing the probability of transition. Some the THEs may thus be envisioning push- rather than pull-motivated full-time entrepreneurship.

We examined also which factors explain the transition intention to full-time entrepreneurship. The most important factor is the motive related to testing: these entrepreneurs have a clear goal first to test their idea on the market and then transit the business in to full-time entrepreneurship. They have also a high growth orientation. These entrepreneurs do not have motives of fulfillment or security. Age is also a significant factor: the younger hybrid entrepreneurs have higher transition intentions. Also a higher share of income from hybrid entrepreneurship has a positive effect on transition intentions.

The results indicate that there are two kinds of hybrid entrepreneurs: those who are engaged in selffulfillment without growth orientation or intention to become a full-time entrepreneur and those who have high goals, high growth orientation and are testing their business idea through part-time entrepreneurship.

\section{Theoretical implications}

It has been proposed that combining salaried employment and entrepreneurship can be interpreted as a testing phase prior to full-time venturing (e.g. Folta et al., 2010, Petrova, 2011), which suggests that partial self-employment in lieu of direct full self-employment is primarily an entry strategy. According to Townsend et al. (2010), the longer would-be entrepreneurs wait to act on their intentions, the less likely they are to start. The long average duration of hybrid entrepreneurship, together the small percentage of HEs rating full-time entrepreneurship within three years as probable, argue strongly that hybrid entrepreneurship must not be automatically associated with nascent full-time entrepreneurship.

Folta et al. (2010) find that only the HEs with the greatest proportion of self-employment income tend to make the transition, and suggest that without a compelling performance signal, individuals persist as HEs. Our results suggest that other factors beyond compelling signal on hybrid performance should be considered. First, while the THEs receive a larger share of their income from the business that PHEs, the difference is not compelling. Second, the THEs are clearly more 
motivated in their entrepreneurship by self-fulfillment than PHEs. If hybrid entrepreneurship, or perhaps the combination of entrepreneurship and salaried employment, offers equal or better opportunities for self-fulfillment than full self-employment, even highly performing HEs may remain in hybrid mode.

As expected based on Petrova (2011), there was a difference in time spent on entrepreneurial activities between THEs and PHEs; THEs invest more time in their business. In this our results differ from those of Viljamaa and Varamäki (2014), whose respondents were not academically educated HEs.

Much of the interest in nascent entrepreneurship stems from the societal desire for increase in startups and growth entrepreneurship. Cassar (2006) argues that an entrepreneur's opportunity costs are a significant determinant of intended scale of venturing activity, i.e. the greater the existing opportunities forsaken in order to undertake a new venture, the larger the scale of the intended new business should be. Cassar's (2006) results show the nascent entrepreneurs with greater income plan bigger ventures. Based on our results with academically educated HEs, the scale of venturing can be miniscule as well: the choice between continuing as HEs rather than becoming fully self-employed apparently hinges on opportunity costs that are high. Academically educated individuals have not only greater human capital and presumably financial resources to invest in their ventures - they also have greater potential for rewarding and well-paid employment. Our results suggest that academic hybrid entrepreneurship is perhaps more likely to benefit society by improving and maintaining job satisfaction and hence contributing to lengthening of careers than by contributing high-growth startups.

All in all our results support Folta et al.'s (2010) argument that persistent hybrids should be considered separately. Hybrid entrepreneurship may often be an entry strategy but examining the phenomenon solely from the perspective of entry strategy is surely misleading. A significant number of HEs is in business with no interest in full-time status. Persistent hybrid entrepreneurship can be viewed as a form of 'risk-free' entrepreneurship. Some HEs are out to get "the best of both worlds": they combine the relative security of salaried employment with the self-fulfillment of entrepreneurship. In fact, their entrepreneurship is characterized by lack of entrepreneurial orientation (see e.g. Aloulou \& Fayolle 2005). Some HEs see part-time entrepreneurship as an insurance policy against career pitfalls. Research on entrepreneurship and occupational choice should consider persistent hybrid entrepreneurship as a distinct category of entrepreneurship. Starting an enterprise does not equate with becoming self-employed at some point; failure to take this into account can lead to faulty conclusions in studies on entrepreneurial activities on one hand, and mask the actual contribution of HEs on the other.

\section{Policy implications}

Based on our results we believe that not only researchers but also policy-makers should recognize that a large proportion of HEs are likely to be persistent hybrids. Entrepreneurship policy has, understandably, focused largely on start-ups with potential for growth and thus for generating employment for others. Less attention has been given to micro firms with limited growth potential. HEs remain a potential pool of (growth) entrepreneurs, but clearly not all hybrids are interested in growth. Policy-makers should, in assessing social and entrepreneurship policy, consider also for example the social security issues relating to persistent hybrid entrepreneurship. If, for example, the legal status of entrepreneur is attained through registering a business, and this act has consequences 
for a person's unemployment benefits even when primary income comes from salaried employment, HEs may find themselves in unexpected difficulties.

Further, full self-employment or employment of others need not be the only societal benefits from entrepreneurial activity. Individuals in salaried employment may find increased motivation and an outlet for entrepreneurial energies in hybrid entrepreneurship; our analysis shows that PHEs are more satisfied with their primary employment than THEs. Is it because intention to become a fulltime entrepreneur is increased by dissatisfaction, or does hybrid entrepreneurship increase or maintain satisfaction with salaried employment? These and other potential benefits of hybrid entrepreneurship remain largely unexplored if attention is restricted to hybrid entrepreneurship as an entry strategy. Hybrid entrepreneurship can be viewed either as an intermediate stage, in which case full-time self-employment is the outcome, or as an end-state in itself; we propose the latter perspective should also be adopted in considering entrepreneurship policy. The pros and cons of mixing work and entrepreneurship from policy perspective need careful consideration.

\section{Limitations and suggestions for further research}

The relatively restricted data set of our study means the applicability of the results in other settings can be questioned. Although there is no inherent reason to assume similar results would not be obtained with larger samples in similar settings, the Finnish socio-economic context with its specific employment and self-employment conditions may have an influence on the results. Further studies exploring hybrid entrepreneurship with larger samples and in a variety of cultural and societal settings are needed.

Future studies should also enquire into the motives and objectives of HEs in greater depth. Qualitative studies as well as further surveys are needed. Belt et al. (2015) find that solopreneurship exhibits specific activity patterns and the applicability of these patterns to HEs should be examined. Also, as significance various forms freelance work and other independent work increases (see e.g. Kitching \& Smallbone 2012; Kuhn 2016), the boundaries of entrepreneurship and employment are likely to blur even further. This poses a challenge for researchers trying to understand the nature of entrepreneurship but also for policy makers.

\section{Acknowledgements}

The authors would like to gratefully acknowledge the financial support of Jenny and Antti Wihuri Foundation.

\section{References}

Akola, E., Heinonen, J., Kovalainen, A., Pukkinen, T. and Österberg, J. (2007). Yrittäjyyden ja palkkatyön rajapinnalla? Työn ja toimeentulon rakentuminen eri ammateissa 2000-luvun Suomessa. Työpoliittinen tutkimus 326/2007. Ministry of Labour, Helsinki.

Aloulou, W. and Fayolle, A. (2005). A Conceptual Approach of Entrepreneurial Orientation within Small Business Context. Journal of Enterprising Culture, 13(01): 21-45.

Alsos, G.A. and Kolvereid, L. (1999). The Business Gestation Process of Novice, Serial and Parallel Business Founders. Entrepreneurship Theory \& Practice, 22: 101-114. 
Belt, P., Paloniemi, K. and Sinisammal, J. (2015). One-Person Enterprises and Business Growth. Journal of Enterprising Culture, 23(03): 381-404.

Bosma, N. and Harding, R. (2007). Global Entrepreneurship Monitor. GEM 2006 Summary Results. Babson Park, MA; London: Babson College; London Business School.

Bosma, N., Acs, Z., Autio, E., Coduras, A. and Levie, J. (2008). Global Entrepreneurship Monitor. GEM 2008 Executive Report. Babson Park, MA; London: Babson College; London Business School.

Burke, A., FitzRoy, F. and Nolan, M. (2008). What makes a Die-hard Entrepreneur?: Beyond the ‘Employee or Entrepreneur’ Dichotomy. Small Business Economics, 31: 93-115.

Cassar, G. (2006). Entrepreneur Opportunity Costs and Intended Venture Growth. Journal of Business Venturing, 21: 610-632.

Curran, J. and Blackburn, R. (2001). Older People and the Enterprise Society: Age and Selfemployment Propensities. Work, Employment and Society, 15: 889-902.

Davidsson, P. (1989). Entrepreneurship - and after? A Study of Growth Willingness in Small Firms'. Journal of Business Venturing, 4(3): 211-226.

Davidsson, P. (1991). Continued Entrepreneurship: Ability, Need, and Opportunity as Determinants of Small Firm Growth. Journal of Business Venturing, 6: 405-429.

Dawson, C. and Henley, A. (2012). "Push” versus “Pull” Entrepreneurship: an Ambiguous Distinction? International Journal of Entrepreneurial Behavior \& Research, 18(6): 697-719.

Douglas, E. and Shepherd, D. (2002). Self-employment as a Career Choice: Attitudes, Entrepreneurial Intentions, and Utility Maximization. Entrepreneurship Theory and Practice, 26(3): 81-90.

Entrepreneurship Review (2010). Employment and Entrepreneurship 60/2010. Ministry of Employment and the Economy, Helsinki.

Eurofound (2011). Emerging Forms of Entrepreneurship. European Foundation for the Improvement of Living and Working Conditions.

http://www.eurofound.europa.eu/emcc/erm/studies/tn1009034s/index.htm [cited 11.6.2014]

Foley, M. R. (1984). What Makes a Small Business Successful? Sheffield Center for Environmental Research. Occasional paper 41.

Folta, T., Delmar, F. and Wennberg, K. (2010). Hybrid Entrepreneurship. Management Science, 56(2): 253-269.

Gelderen, M. van, Thurik, R. and Bosma, N. (2005). Success and Risk Factors in the Pre-Startup Phase. Small Business Economics, 24: 365-380.

Gray, C. (2004). Age Effects on Small Firm Growth and Strategic Objectives. The 34th efmd EISB Conference Abstracts Proceedings, 8-10 September 2004, Turku.

Gruenert, J. (1999). Second Job Entrepreneurs. Occupational Outlook Quarterly, 43(3): 18-26. 
Hart, M., Anyadike-Danes, M. and Blackburn, R. (2004). Entrepreneurship and Age in the UK: Comparing Third Age and Prime Age New Venture Creation Across the Regions. Paper presented at the RENT XVIII, Copenhagen, November.

Heinonen, J., Kovalainen, A., Paasio, K., Pulkkinen, T. and Österberg, J. (2006). Palkkatyöstä yrittäjäksi: Tutkimus yrittäjäksi ryhtymisen reiteistä sosiaali- ja terveysalalla sekä kaupallisella ja teknisellä alalla. Työvoimapoliittinen tutkimus 297/2006. Työministeriö, Helsinki.

Kitching, J. and Smallbone, D. (2012). Are Freelancers a Neglected Form of Small Business? Journal of Small Business and Enterprise Development, 19(1): 74-91.

Kirkwood, J. (2009). Motivational Factors in a Push-pull Theory of Entrepreneurship. Gender in Management: An International Journal, 24(5): 346-364.

Kuhn, K. (2016). The Rise of the "Gig Economy" and Implications for Understanding Work and Workers. Industrial and Organizational Psychology, 9(1):157-162.

Lange, T. (2012). Job Satisfaction and Self-employment: Autonomy or Personality? Small Business Economics, 38: 165-177.

Lith, P. (2010). Yrittäjäksi palkkatyön tai eläkkeen ohella, Tieto \& Trendit, 7. Available at http://www.stat.fi/artikkelit/2010/art_2010-11-10_005.html [14.4.2014]

Markantoni, M., Koster, S. and D. Strijker (2012). Side activity Entrepreneur: Lifestyle or Economic Oriented in Karlsson, J. and R., Stough (eds.). Agglomeration, Clusters and Entrepreneurship: Studies in Regional Economic Development. Edward Elgar.

Moore, C. and Mueller, R. (2002). The Transition from Paid to Self-employment in Canada: The Importance of Push Factors. Applied Economics, 34: 791-801.

Mungaray, A. and Ramirez-Urquidy, M. (2011). Full and Part-time Entrepreneurship and the Supply of Entrepreneurial Effort: Evidence from Mexican Microenterprises. Journal of Developmental Entrepreneurship, 16(4): 441-458.

Petrova, K. (2011). Part-time Entrepreneurship, Learning and Ability. Journal of Management Policy and Practice, 12(1): 64-75.

Petrova, K. (2012). Part-time Entrepreneurship and Financial Constraints: Evidence from the Panel Study of Entrepreneurial Dynamics. Small Business Economics, 39(2): 473-493.

Pk-yritysbarometri (2014). http://www.yrittajat.fi/fi-FI/suomenyrittajat/tutkimustoiminta/pkyritysbarometri-2-2014/

Raffiee, J., and Feng, J. (2014). Should I Quit My Day Job?: a Hybrid Path to Entrepreneurship. Academy of Management Journal, 57(4): 936-963.

Reynolds, P., Carter, N., Gartner, W. and Greene, P. (2004). The Prevalence of Nascent Entrepreneurs in the United States. Small Business Economics, 23(4): 263-284.

Segal, G., Borgia, D. and Schoenfeld, J. (2005). The Motivation to Become an Entrepreneur. International Journal of Entrepreneurial Behaviour \& Research, 11(1): 42-57. 
Singer, S., Simpson, R., Mordi, C. and Okafor, C. (2011). Motivation to Become an Entrepreneur: a Study of Nigerian Women's Decisions. African Journal of Economic and Management Studies, 2(2): 202-219.

Stenholm, P., Suomalainen, S., Kovalainen, A., Heinonen, J. and Pukkinen, T. (2015). Global Entrepreneurship Monitor. Finnish 2014 report. Turku School of Economics, University of Turku, Series A Research Reports A1/2015.

Stenholm., P, Kovalainen, A., Heinonen J. and Pukkinen, T. (2012). Global Entrepreneurship Monitor. Finnish 2012 report. Turku School of Economics, University of Turku, Series A Research Reports A1/2013.

Thorgren, S., Nordström, C. and Wincent, J. (2014). Hybrid Entrepreneurship: the Importance of Passion. Baltic Journal of Management, 9(3): 314-329.

Tornikoski, E., Viljamaa, A. and Varamäki, E. (2015). Hybrid Entrepreneurship during Retirement: Comparison of Motives and Aspirations in Sappleton, N. and Lourenco, F. (eds.) Entrepreneurship, Self-Employment and Retirement, 187-208. Palgrave Macmillan.

van Praag, C. and Versloot, P. (2007). What is the Value of Entrepreneurship? A Review of Recent Research. Small Business Economics, 29: 351-382.

Varamäki, E., Sorama, K., Viljamaa, A., Heikkilä, T. and Salo, K. (2012). Eteläpohjalaisten sivutoimiyrittäjien kasvutavoitteet sekä kasvun mahdollisuudet. Publications of Seinäjoki University of Applied Sciences Research Reports A 11. Seinäjoki University of Applied Sciences, Seinäjoki

Viljamaa, A. and Varamäki, E. (2014). Persistent vs. Transitory Hybrid Entrepreneurs - An Exploration of Profiles, Motives and Ambitions. Proceedings of RENT XXVIII Conference Research in Entrepreneurship and Small Business, 19.-21.11.2014, Luxemburg.

Viljamaa, A., Varamäki, E., Tornikoski, E. and Sorama, K. (2014). Hybrid Entrepreneurship Exploration of Motives, Ambitions and Growth. Proceedings of ICSB World Conference on Entrepreneurship, 11.-14.6. 2014, Dublin.

Viljamaa, A., Varamäki, E., Heikkilä, T., Joensuu, S. and Katajavirta, M. (2015). Sivutoimiyrittäjät - pysyvästi sivutoimisia vai tulevia päätoimisia? Publications of Seinäjoki University of Applied Sciences Reports B 103. Seinäjoki University of Applied Sciences, Seinäjoki.

Westhead, P. and Wright, M. (1998). Novice, Portfolio, and Serial Founders: Are They different? Journal of Business Venturing, 13: 173-204. 